\title{
THE TRIAL OF THE TORMENTED ROWLAND EDWARDS
}

\section{Hon Justice David Collins*}

\section{INTRODUCTION}

"The law should take its course". With this pronouncement, Lieutenant-General Sir William Jervois, Governor of New Zealand, sealed the fate of Rowland Herbert Edwards. The Governor's words conveyed his confirmation of the death sentence that had been imposed upon Edwards for the murder of his wife, Mary, following his trial in the Supreme Court at Napier. ${ }^{1}$

Infamy shrouded Edwards when, on 11 February 1884, he was charged with having murdered Mary and their four children the previous night. His trial was limited, however, to the charge that he had murdered his wife. Edwards' trial began and ended on 10 June 1884. After hearing evidence from 12 witnesses, closing addresses and the Judge's summing up, the jury returned its verdicts at $5.25 \mathrm{pm}$, having retired for just 19 minutes. Gillies J, the presiding judge, immediately made some brief sentencing remarks, donned the black cap and sentenced Edwards to death. ${ }^{2}$ The following day, after a notice of nolle prosequi was filed by the Crown, ${ }^{3}$ Gillies $\mathrm{J}$ entered stays of prosecution in relation to the part of the indictment that alleged Edwards had also murdered his four children.

Upon reviewing the Judge's notes of evidence, the Governor, in accordance with the statutory language of the day, "intimated" his "pleasure" with the sentence. ${ }^{4}$ Edwards was executed at Napier

* Court of Appeal. The author acknowledges the assistance of his clerks, James Tocher and Victoria Squires.

1 The Governor's pronouncement was recorded in a memorandum initialled by the Governor and other members of the Executive Council dated 25 June 1884.

2 The death sentence for murder was, at the time, prescribed in the Offences Against the Person Act 1867, s 2 , which provided that "[u]pon every conviction for murder the Court shall pronounce sentence of death".

3 Notice by the Crown of its intention not to proceed with a prosecution.

4 Criminals Executions Act 1883, s 4:

Whenever sentence of death is pronounced by any Court or Judge, it shall be the duty of the Sheriff of the district in which the execution is to take place to carry out such sentence, but he shall not proceed to execute the same till he has received an intimation of the Governor's pleasure with respect to such sentence. 
Prison on 15 July $1884,{ }^{5}$ one of 85 prisoners to have been so punished in New Zealand. His death brought to a close a tragic and disturbing chapter in the annals of colonial New Zealand.

\section{THE TRAGEDY}

Edwards was born in Iver, Buckinghamshire in 1850. Mary was born the following year. She married her first husband, Thomas Slatford in 1870, who died soon after the birth of their son, Thomas. In 1873, Edwards and Mary married in Hackney, London. They immigrated to New Zealand, arriving at Napier on 6 July 1874 aboard the Halcione. Passenger shipping records reveal they were accompanied by Mary's son, Thomas, aged two. There is, however, no record of Thomas in the events that unfolded 10 years after the family arrived in New Zealand.

Newspaper reports published on 11 February 1884 described Edwards as "a man of some education and a practical engineer" who received remittances from England. ${ }^{6}$ He is said to have received £1,000 from "home" in 1881 with which he bought a property at Ormondville, a small hamlet in southern Hawke's Bay where, prior to the tragic events of 10 February 1884, he lived with Mary and their children: Robert (seven), Ella (five), Arthur (three) and Maud, who was born in 1883.

Edwards was employed as a platelayer on the Napier-Woodville railway line. His tasks included the inspection and maintenance of the railway line, including a bridge spanning the Makotuku River.

Contemporary newspaper reports say Edwards had a history of drinking. One article stated that "for some years [Edwards] was chief engineer on one of the coastal steamers but was discharged for drunkenness". ${ }^{7}$

Some residents of Ormondville said that Edwards had been drinking heavily during the course of January 1884 and that he had been last seen in a drunken state on Tuesday 5 February 1884. Jeremaiah Linehan, the local publican, said in Edwards' trial that on Saturday 9 February 1884, Edwards went to the Ormondville Hotel, where he drank just one beer. Linehan testified that the only time he had seen Edwards adversely affected by alcohol was in January 1884. Linehan's observations about Edwards' resilience to alcohol were confirmed by Constable Schulz, the local policeman who, during the course of Edwards' trial, explained that he had only seen Edwards affected by alcohol on one occasion, and even then, he was not sufficiently intoxicated to be arrested. Edwards had, however, built up a significant debt at the Ormondville Hotel. By 10 February 1884, he owed Linehan £7/19s for alcohol that he had purchased but not paid for during the previous three years. ${ }^{8}$

5 New Zealand had abolished public executions in 1858: see the Execution of Criminals Act 1858, s 1.

6 "Distressing Murder at Ormondville" Hawke's Bay Herald (Napier, 11 February 1884) at 4.

7 At 4 .

8 Approximately $\$ 1,500$ in present day currency. 
At about 3.00 pm on Sunday 10 February 1884, Edwards' son, Robert, arrived at the Ormondville Hotel with a note asking for a small flask of brandy. It was said by Linehan during Edwards' trial that the note was not in Edwards' handwriting. Nevertheless, Linehan obliged, sending Edwards a flask containing "not quite half a pint" of brandy, which equated to about three glasses. ${ }^{9}$

Neighbours who lived in the community saw Edwards at various times throughout Sunday 10 February. He was described as being sober and in the company of one or more of his children. Mrs Edwards was also seen at various times that day. At about $6.00 \mathrm{pm}$ she spoke to William West, who lived nearby, and told him her husband "had a little attack of some complaint" and that she had hidden his gun and slashing hook. ${ }^{10}$ West thought Mrs Edwards seemed to be in good humour and that she was laughing and cheerful. That evening Edwards and the three eldest children went to church while Mary stayed at home with Maud.

The solitude of Ormondville was shattered that night when, at about $2.00 \mathrm{am}$, Edward Plank was woken by the sound of his dog barking. He then heard Edwards standing at his door calling out for a loaded gun and a drink of water. Plank did not respond, but instead followed Edwards as he walked towards the home of William Pike in the community of Makotuku, about three kilometres from Ormondville, who was also awoken by Edwards' commotion. They both went looking for Edwards but soon decided to rouse Constable Schulz, who also lived at Makotuku and who joined their search for Edwards. Plank went to Edwards' home and was soon accompanied by Pike and the policeman. Constable Schulz called out to Mrs Edwards and, after being met with silence, he entered the property. A short time later he called out to Pike and Plank to assist him. When all three were in the house, a match was struck revealing the three eldest children lying in bed. Their throats had been cut. Mrs Edwards and the baby were lying on another bed. Their throats had also been cut. Plank found a blood-stained knife on the bedroom floor, which he handed to Constable Schulz. The three men exited the home.

While Plank alerted the neighbours, Pike went searching for Edwards along the railway line. Pike was soon joined again by Plank. They found Edwards hiding in the trestles of the Makotuku bridge. When Plank called out to Edwards he replied, "I have killed the old woman and the children". ${ }^{11}$ Edwards threatened to jump from the bridge but he was talked into joining Plank and Pike. He then walked with them towards Makotuku where they were met by Constable Schulz. When found, Edwards had blood on his shirt and arms. He explained he had attempted to cut his own throat, but

9 "Ormondville Resident Magistrate's Court" Hawke's Bay Herald (Napier, 14 February 1884) at 3.

10 Gillies J, transcript of evidence, 10 June 1884 at 4.

11 At 3 . 
the knife was blunt and that his neck was "sore and tender" and he therefore "did not finish it". ${ }^{12} \mathrm{He}$ was taken to Waipukurau Hospital for treatment.

Examination of the scene of the homicides revealed Edwards had taken a heavy piece of wood, whittled a handle at one end, and used the makeshift club to strike the heads of the victims, rendering them unconscious. Thereafter he cut their throats.

So, what was Edwards' reason for this extraordinary act of barbarism? The first hints of his explanation were at the Makotuku bridge when, after confessing to having killed his wife and children, he said he did not want them to be "roasted alive". ${ }^{13}$ This explanation was expanded upon when, on Tuesday 12 February 1884, Edwards told Constable Schulz that he wanted to tell him what had happened. Constable Schulz recorded Edwards' explanation in the following way: ${ }^{14}$

I had very little sleep for four nights before the murders. I was all right on Sunday, but towards evening I got strange fancies in my head. I fancied I heard a crowd of people outside the house, threatening to burn me and my family alive. I then got the piece of firewood and got it ready to defend myself and family. I waited some time for them to come. My wife wanted to go for you [Constable Schulz], and asked me to go myself, as she was sure that you would stop with us for the night if asked to do so, but I was afraid of going myself or of letting her go, on account of my fancies, and the voices I heard outside. I got better, and told her I thought I would be all right. She put the piece of wood in the fire, but I heard them coming again and took it off, put it beside me and watched the door. My wife went in and out of bedroom different times, and laid down with exhaustion, as she had very little sleep for five nights. All at once I heard a whole crowd outside singing out they were going to burn us all alive. I jumped up and went in the bedroom and knocked my wife senseless with a piece of wood, and then the children. I did this that they should not feel the pain when I was cutting their throats. I could not stand to see them burned alive. I then cut my own throat, but the knife being blunt I could not finish it, as I heard them coming. I crawled under the big bed out of the road. I lay there some time. I then heard them at the back of the house. I got out, ran into the garden and hid behind a tree, but they would not leave me. I then ran across the paddock towards Plank's, but they followed me. I left there and went to Pike's, but I heard them again, and hid under the bridge, as I thought they would not follow me there. When I told Plank I would not be taken I did not think of you [Constable Schulz] or the police. I was speaking of the crowd round me.

Poignantly, at the end of his confession, Edwards said to the constable: ${ }^{15}$

12 At 3

13 "Supreme Court - Criminal Sittings" Hawke's Bay Herald (Napier, 11 June 1884) at 3.

14 Gillies J, transcript of evidence, 10 June 1884 at 15-16.

15 At $16-17$. 
I believe I'll be hung for it; I deserve it. I hope they won't keep me long. I want to meet my wife and family. I think I will go to the same place as they and they will forgive me.

Two days later, on 14 February 1884, Edwards made a further statement to Constable Schulz that was recorded in the following way by the constable: ${ }^{16}$

If the old woman had not put the money out of my road, or if she had sent for you, I believe it would never

have happened. I am sorry now I did not send for you.

\section{THE PLEA}

Newspaper reports of the trial said that at the commencement of the trial, Edwards pleaded guilty "but said he was not in his right mind at the time the crime was committed". ${ }^{17}$ Gillies J then treated Edwards' plea as one of not guilty.

\section{THE CROWN CASE}

When opening the case for the Crown, Mr Cottrell said that Edwards "had been of most intemperate habits" and had murdered his wife "through the influence of drink" when he became angry at her interfering "in his drinking habits". ${ }^{18}$

The Crown's view of Edwards' motivation was based on the supplementary remarks Edwards made to Constable Schulz on 14 February. There is, however, no reference in reports of the trial as to why the Crown thought Edwards considered it necessary to also slay his four children. No doubt, the Crown did not consider it was required to address this lacuna in its theory as to Edwards' motive because the trial was only concerned with the murder of Mrs Edwards.

\section{THE COMMON LAW CRIME OF MURDER}

At the time of Edwards' trial, the definition of murder was to be found in the common law. It was not until 1893, when Parliament enacted the Criminal Code Act, that the crime of murder, along with almost every other criminal offence in New Zealand, was codified in statute. ${ }^{19}$ At common law, murder was "unlawful homicide with malice aforethought". ${ }^{20}$ According to Sir James Stephen, the pre-eminent authority on criminal law in England during the second half of the 19th century, malice

16 At 17.

17 "Supreme Court - Criminal Sittings", above n 13, at 1.

18 At 3.

19 The Criminal Code Act 1893 was modelled upon a draft Bill compiled in England in 1879 by Sir James Fitzjames Stephen. The Bill drafted by Stephen was never enacted in England. It was, however, adopted in Canada (1892), Queensland (1899), Western Australia (1902) and Tasmania (1924), as well as in New Zealand.

20 James Fitzjames Stephen A History of The Criminal Law of England (MacMillan and Co, London, 1883) vol 3 at 80 . 
meant wickedness. ${ }^{21}$ Instances of malice aforethought referred to by Stephen included: an intent to kill; an intent illegally to do great bodily harm; and wanton indifference to life in the performance of an act likely to cause death, whether lawful or not. ${ }^{22}$

\section{EVIDENCE OF EDWARDS' (IN)SANITY}

The first recorded sign of Edwards suffering from mental instability was on 12 July 1883, when he was arrested by Constable Schulz on a charge of lunacy. ${ }^{23}$ The constable had been called to Edwards' home after Charles West (son of William West) and another neighbour had subdued Edwards by tying his hands and feet together. They had taken this course of action after Edwards was seen to be "jumping over logs" and behaving in an agitated fashion. ${ }^{24} \mathrm{He}$ was remanded for a medical examination at the Napier Asylum where he was seen by Dr Hitchings. The doctor said in Edwards' trial for the murder of his wife that his impression was that Edwards had been drinking and showed "slight symptoms of delirium tremens about him". ${ }^{25}$ Dr Hitchings discharged Edwards, believing him to be sane.

Three months later, Edwards was again arrested by Constable Schulz on a charge of lunacy after the constable had been informed that Edwards had threatened to cut the throat of his son Robert and blow up the family with gunpowder. When he was arrested, Edwards spoke to the constable about "a crowd of beings" around him that were "going to shoot [him]" because he had "betrayed the secrets of the Masons". 26

Edwards was again remanded to the asylum in Napier where he was seen by both Dr Hitchings and Dr Matthews. Neither doctor thought that Edwards showed signs of insanity. On this occasion, Edwards was kept in custody for 13 days by Constable Schulz. During part of that time he was cared for by his wife Mary. Constable Schulz was satisfied, that when he released Edwards into the care of his wife, he was not showing symptoms of mental unwellness.

21 James Fitzjames Stephen A General View of the Criminal Law of England (MacMillan and Co, London, 1863) at 116.

22 At 116

23 Lunatics Act 1882, s 12, which empowered every constable, who knew that any person "wandering at large [was] believed to be a dangerous lunatic", to immediately apprehend that person and take them before a Resident Magistrate.

24 "Supreme Court - Criminal Sittings", above n 13, at 3.

25 Gillies J, transcript of evidence, 10 June 1884 at 20. Delirium tremens is a condition characterised by rapid confusion and hyperactivity usually caused by alcohol withdrawal. The condition is examined later in this article.

26 At 18. 
Rudolph von Mirbach, a surgeon at Waipukurau Hospital, conducted post-mortem examinations of Mrs Edwards and the deceased children. Dr von Mirbach also conducted an assessment of Edwards' state of mind by asking him why he had not cut his throat deeper and whether he felt pain when he made the shallow incision. Edwards' answer reflected what he had previously told Constable Schulz, namely that the knife was blunt and his skin felt tender. This answer led Dr von Mirbach to conclude Edwards was "quite sane". ${ }^{27}$ The doctor's explanation for this conclusion was recorded by Gillies J in the following way in his bench book: ${ }^{28}$

An insane man who makes up his mind to cut his own throat does not feel pain. I have seen a few cases of homicidal mania. In this case the paroxysms might have subsided through the killing of the other persons. I ascribed his acts to the effects of drinking a flask of brandy - that is the flask I said would contain about three glasses - not an excessive quantity for him. The statements of delusion to Constable Schulz are like those of delirium tremens.

At this point in his evidence, Dr von Mirbach was asked questions by Gillies J to which he responded that Edwards showed "no sign of permanent insanity about him" when he was examined on 11 February. ${ }^{29}$

When Dr Matthews gave his evidence about his earlier examination of Edwards in October 1883, he explained that his attention had not been brought to the delusions Edwards was reported to have experienced. Dr Matthews then said in his evidence: "[l]ooking to the facts in evidence [it is] quite possible he may have been suffering from homicidal mania - that has been known to break out suddenly." 30

At this point, Gillies J asked Dr Matthews if homicidal mania may arise from delirium tremens. Dr Matthew responded: "[i]f not from that or other apparent cause then from a deterioration of the brain. As a rule other symptoms of insanity accompany homicidal mania."31

Dr Matthews told the jury that he knew of no indication of insanity in Edwards "save [for the] commission of this crime". ${ }^{32}$
27 At 19.
28 At $19-20$.
29 At 20.
30 At 21 .
31 At 21.
32 At 21 
The final witness was Dr de Lisle, a medical practitioner in Napier, who examined Edwards the month prior to his trial. Dr de Lisle said that Edwards "seemed of perfectly sound mind" and that when asked about the "delusions of February" Edwards said that he "was in the horrors". ${ }^{33}$

\section{THE CONCLUSION OF THE TRIAL}

At the conclusion of the evidence, Mr Cornford, one of the counsel for the Crown, and Mr Lee, Edwards' lawyer, addressed the jury. In his closing address, Mr Cornford focused on Edwards' statement to Constable Schulz on 14 February as proof that he "had committed the deed in a momentary gust of revengeful feeling" towards Mrs Edwards for her apparent interference in his drinking. ${ }^{34}$ In response to the suggestion that Edwards might have been insane, Mr Cornford submitted that such a defence would only succeed if Edwards was "absolutely demented at the time", and did not know "anything of what he was doing". ${ }^{35}$

Mr Lee urged the jury to return a verdict of not guilty by reason of insanity. ${ }^{36}$ He focused upon Edwards' delusion that people were about to burn him and his family and submitted "that delusion overpowered [Edwards'] mind so that he did not know right from wrong", and that he was therefore "not guilty in the eyes of the law". ${ }^{37}$

Gillies J, who trained as a lawyer in Scotland, ${ }^{38}$ then summed up to the jury saying, in relation to the defence of insanity, that the onus was on Edwards to prove his lack of sanity at the time he killed his wife. According to the local newspaper report, the Judge then told the jury: ${ }^{39}$

Supposing the prisoner to have been suffering from mania at the time the crime was committed, that mania might have been primarily due to indulgence and liquor, or due to brain disease as a secondary result of that indulgence. For the plea of insanity to amount to a bar to punishment, it must be shown that the

33 At 21.

34 Supreme Court - Criminal Sittings", above n 13, at 3.

35 At 3

36 Lunatics Act, s 9: "[a]cquittal on ground of insanity".

37 "Supreme Court - Criminal Sittings", above n 13, at 3.

38 Gillies J was born on the Isle of Bute, Scotland in 1828. He trained as a lawyer in his father's law firm in Scotland before working for a textile merchant in Manchester. He and his family immigrated to New Zealand in 1852, where he passed the New Zealand Bar examinations and resumed the practice of law in Dunedin in 1857 before embarking upon a political career, which saw him serve four terms in Parliament between 1860 and 1875. He held a variety of Cabinet positions, including Attorney-General before being appointed to the Supreme Court Bench in 1875.

39 "Supreme Court - Criminal Sittings", above n 13, at 3. There is no record of the Judge's summing up in his bench book or his report to the Governor. 
insanity, either at the time of the offence being committed, or when the trial for the offence ensued, was

of such a nature as to entirely deprive the prisoner of the use of his reason.

It is not apparent why Gillies J referred to Edwards proving his insanity at the time of his trial, as Edwards' fitness to stand trial was not in issue. Fitness to stand trial and insanity were, by the time of Edwards' trial, distinct concepts. In $R v$ Pritchard, it had been explained that in order to be fit to stand trial a defendant must be "of sufficient intellect to comprehend the course of the proceedings in the trial so as to make a proper defence - to know he may challenge [jurors] ... and to comprehend the details of the evidence". ${ }^{40}$ The defence of insanity, which relates to a defendant's state of mind at the time of his or her alleged offending, involved the application of the McNaughton Rules, which engaged different considerations that are examined in further detail later in this article.

Following the verdict of guilty, Gillies J addressed Edwards saying: ${ }^{41}$

The verdict of the jury is that you are guilty of wilful murder. It is not for me to harrow your feelings by referring to the atrocious nature of the crime you have committed. There is no doubt in my mind that yours is one of the long list of cases caused very immediately by intemperance. It is a sad thing to contemplate, but if people will give way to that vice they cannot know where it will end. As I said, it is no duty of mine to enlarge upon the grave nature of your crime, but only to pronounce, in the name of the law, the dread sentence that is attached to the crime of wilful murder.

On 13 June 1884, Gillies J transcribed a copy of his notes of evidence for the Governor's consideration. In his covering letter to the Minister of Justice, Gillies J said: ${ }^{42}$

The defence set up was insanity but it did not appear to me or to the jury that the prisoner was any further insane than under a temporary attack of delirium tremens.

\section{THE DEFENCE OF INSANITY IN 1884}

The earliest references to the defence of insanity can be found in the Code of Hammurabi, written in the 18th century BC. ${ }^{43}$ References to the defence can also be found in the writings of the Ancient Greeks. For example, in Herakles, an Athenian tragedy written by Euripides, Herakles was absolved from responsibility for the murder of his family because the killings took place during a period when

$40 R v$ Pritchard (1836) 7 C \& P 303, 173 ER 135 at 304.

41 "Supreme Court - Criminal Sittings", above n 13, at 3.

42 Letter from Gillies J to the Attorney-General (13 June 1884) at 1-2.

43 The Code of Hammurabi King of Babylon About 2250 BC (Robert Francis Harper (translator), The University of Chicago Press, Chicago, 1904). See also Randy Borum and Solomon M Fulero "Empirical Research on the Insanity Defence and Attempted Reforms: Evidence Toward Informed Policy" (1999) 23 Law Hum Behav 375. 
he was beset by temporary insanity. ${ }^{44}$ Sir William Blackstone, in his 1769 Commentaries on the Laws of England, recorded that "in criminal cases ... idiots and lunatics are not chargeable for their own acts, if committed when under these incapacities". The policy that underpinned this aspect of the common law was said by Blackstone to be that "madness alone punishes a madman". ${ }^{45}$

The scope of the defence of insanity was tested in $R v$ Oxford, in which the defendant was charged with treason following his failed attempt to assassinate Queen Victoria. ${ }^{46}$ The defence case included testimony from family and friends of Oxford, who said that his father and grandfather were alcoholics and had exhibited signs of mental illness. Medical practitioners testified that due to "brain disease" Oxford was either an imbecile or incapable of controlling himself. ${ }^{47}$ Oxford was found by the jury to be not guilty by reason of insanity. ${ }^{48}$

The trial of Daniel McNaughton, who attempted to assassinate the then British Prime Minister, Rt Hon Sir Robert Peel, but instead mistakenly killed Peel's secretary, became the catalyst to settle the common law defence of insanity. ${ }^{49}$ The McNaughton Rules were formulated by a panel of judges, presided over by Sir Nicholas Tindal, Chief Justice of the Common Pleas, at the behest of the House of Lords after McNaughton was found not guilty of the murder of Peel's secretary. The judicial panel answered a series of hypothetical questions and in doing so formulated the defence of insanity in the following way: 50

... every man is presumed to be sane, and ... to establish a defence of insanity, it must be clearly proved that, at the time of the committing of the act, the party accused was labouring under such defect of reason, from disease of the mind, as not to know the nature and quality of the act he was doing; or if he did know it, that he did not know he was doing what was wrong.

The McNaughton Rules became the standard test for insanity in common law jurisdictions and provided the foundation for the statutory defence of insanity set out in s 23 of the Criminal Code Act

44 Grief Lessons: Four Plays by Euripides (Anne Carson (translator), New York Review Books, New York, 2006).

45 William Blackstone Commentaries on the Laws of England: A Facsimile of the First Edition of 1765-1769 (The University Chicago Press, Chicago, 1979) vol 4 at 24.

$46 \quad R v$ Oxford (1840) 9 C \& P 525, 173 ER 941.

47 See Mark Stevens Broadmoor Revealed: Victorian Crime and the Lunatic Asylum (Pen and Sword Books, Barnsley (UK), 2013) at 4.

48 After spending decades in Bedlam and Broadmoor Hospitals, Oxford was discharged on the condition he leave England immediately. He spent the rest of his life in Melbourne leading a respectable life under an assumed name.

49 M'Naghten's Case (1843) $10 \mathrm{Cl} \&$ Fin 200, 8 ER 718 (HL).

50 At 210. 
1893. ${ }^{51}$ The McNaughton Rules could be distinguished however, from the law of insanity in Scotland, where Gillies J received his initial legal education. In Scotland, the defence of insanity required a defendant to demonstrate "absolute alienation" of his or her reason. ${ }^{52}$

If Edwards were to have escaped the noose, he would have needed to have established his insanity on the night of 10 February 1884 by invoking the McNaughton Rules, which Stephen summarised in the following way: ${ }^{53}$

The question to be tried is, whether the prisoner acted with intention, will and, malice. In popular language,

Was it his act? Could he help it? Did he know it was wrong?

The fact that a defendant's state of insanity was only temporary did not necessarily undermine the defence. Stephen explained that: ${ }^{54}$

... [the existence of temporary] insanity or insane delusion ... is evidence to show that the prisoner's mind was so disturbed that he did not know that the act was wrong, that he could not form a reasonable judgment on it.

Intoxication, however, was not in itself regarded as a disease of the mind. The common law did not countenance a defendant escaping the consequences of criminal conduct brought about by the

51 Two of the answers provided by the Judicial Panel to the questions asked by the House of Lords led to the concept known as the "specific delusions rule", which established that where a defendant committed a crime whilst suffering from a delusion about a particular factual matter, in circumstances where the existence of that factual circumstance would not have justified or excused the defendant's conduct, he or she would nevertheless be guilty. Stephen subsequently (but prior to 1884) explained that this rule was redundant, as a specific delusion, even if not a justification in itself, could provide an evidential basis for concluding the defendant was incapable of appreciating his or her conduct was wrong: James Fitzjames Stephen A History of The Criminal Law of England (MacMillan and Co, London, 1883) vol 2 at 163-164. Stephen's approach is now reflected in s 23(3) of the Crimes Act 1961, which states:

Insanity before or after the time when he or she did or omitted the act, and insane delusions, though only partial, may be evidence that the offender was, at the time when he or she did or omitted the act, in such a condition of mind as to render him or her irresponsible for the act or omission.

52 Baron Hume Commentaries on the Law of Scotland, Respecting Crimes (2nd ed, Bell \& Bradfute, Edinburgh, 1819), in which the author explained the law of insanity in Scotland in the following way:

To serve the purpose of a defence in law, the disorder must therefore amount to an absolute alienation of reason, ut continua mentis alienatione, omni intellectu careat - such a disease as deprives the patient of the knowledge of the true aspect and position of things about him - hinders him from distinguishing friend from foe - and gives him up to the impulse of his own distempered fancy.

According to the Scottish Law Commission, this statement of the law of the defence substantially reflected the law of Scotland through to modern times: Scottish Law Commission Report on Insanity and Diminished Responsibility (Report 195, July 2004) at [2.2].

53 James Fitzjames Stephen A General View of the Criminal Law of England, above n 21, at 91.

54 At 92. 
voluntary consumption of alcohol. ${ }^{55}$ Nevertheless, the common law distinguished between "drunkenness", for which the defence of insanity was not available and diseases caused by the consumption of alcohol, such as delirium tremens. ${ }^{56}$ The law was summarised in the following way by an authority on medical jurisprudence: ${ }^{57}$

While drunkenness is no excuse, delirium tremens caused by drinking, if it produces such a degree of madness, although only temporary, as to render a person incapable of distinguishing right from wrong, relieves him from criminal responsibility for any act committed by him while under its influence.

An illustration of the way delirium tremens could lay a foundation for the defence of insanity can be found in $R v$ Davis. In that case, Stephen $\mathrm{J}$ (as he had then become) summed up to a jury in a case of attempted murder in which the defendant had been examined by two doctors and was found to be suffering from delirium tremens at the time of his alleged offending. ${ }^{58}$ Stephen J's summing up contained the following statements: ${ }^{59}$

Nobody must suppose—and I hope no one will be led for one moment to suppose — that drunkenness is any kind of excuse for crime ... But drunkenness is one thing and the diseases to which drunkenness leads are different things; and if a man by drunkenness brings on a state of disease which causes such a degree of madness, even for a time, which would have relieved him from responsibility if it had been caused in any other way, then he would not be criminally responsible. In my opinion, in such a case the man is a madman, and is to be treated as such, although his madness is only temporary ... Drunkenness is no excuse, but delirium tremens caused by drunkenness may be an excuse if you think it produces such a state of mind as would otherwise relieve him of responsibility ... If you think there was a distinct disease caused by drinking, but differing from drunkenness, and that by reason thereof he did not know that the act was wrong, you will find a verdict of not guilty on the ground of insanity...

The jury duly found Davis not guilty on the ground of insanity. Subsequently, in Director of Public Prosecutions $v$ Beard, the House of Lords endorsed the approach taken by Stephen J in $R v$ Davis. ${ }^{60}$

The issues upon which Gillies $\mathrm{J}$ needed to instruct the jury, if they were to properly apply the McNaughton Rules were:

$55 \quad R v$ Meakin (1836) 7 C \& P 297, 173 ER 131

56 Director of Public Prosecutions v Beard [1920] AC 479 (HL).

57 William Ramsay Smith Medical Jurisprudence from the Judicial Standpoint (Stevens \& Sons, London, 1913) at 196.

$58 R v$ Davis (1881) 14 Cox CC 563.

59 At 564

60 Director of Public Prosecutions v Beard, above n 56, at 501. 
- $\quad$ whether, at the time he killed his wife (and children), Edwards was suffering from a disease of the mind; and

- $\quad$ whether Edwards understood the nature and quality of the acts he performed when killing his wife (and children); or

- $\quad$ whether Edwards knew his acts were wrong.

Before analysing these issues, it is necessary to first examine how medical science may have viewed Edwards' circumstances.

\section{EDWARDS' MEDICAL CONDITIONS}

Considerable caution should be exercised before commenting retrospectively on any person's medical condition, let alone 134 years after their death. We do, however, have the benefit of observations of four medical practitioners who examined Edwards between July 1883 and the month prior to his trial. We also have the benefit of the observations of a number of persons who knew Edwards and his own comments about his condition, particularly on the evening he took the lives of his wife and children.

During the course of Edwards' trial, references were made to him possibly suffering delirium tremens on the night of 10 February 1884. Dr Matthews and Dr von Mirbach also referred to "homicidal mania", but the latter rejected any possibility that Edwards was suffering from that condition on the fateful night.

\section{A Delirium Tremens}

Descriptions of what is now referred to as "delirium tremens" can be found in medical literature dating back to the late 18th century. ${ }^{61}$ The condition has a number of common names, including the "horrors", 62 the term that Edwards used to describe his condition to Dr de Lisle when referring to his state of mind on the night he killed his wife and children. In 1813, the term "delirium tremens" was coined, by which time it was recognised as a condition that could affect someone who suffers the effects of alcohol withdrawal. ${ }^{63}$

One early description of the symptoms of delirium tremens bears repeating: ${ }^{64}$

61 Theodore A Stern and others "Current Approaches to the Recognition and Treatment of Alcohol Withdrawal and Delirium Tremens: 'Old Wine in New Bottles' or 'New Wine in Old Bottles"' (2010) 12(3) Prim Care Companion J Clin Psychiatry PCC.10r00991.

62 Dan Baldwin and George Sewell Just the FAQ's, Please, About Alcohol and Drug Abuse: Frequently Asked Questions from Families (PublishAmerica, Frederick (MD), 2002) at ch 4.

63 Thomas Sutton Tracts on Delirium Tremens, on Peritonitis, and on some other internal Inflammatory Affections, and on the Gout (Thomas Underwood, London, 1813).

64 Samuel Burton Pearson "Observations of Brain-Fever"(1813) 9 Edinb Med Surg J 326 at 327. 
It is preceded by tremors of the hands; restlessness; irregularity of thought; deficiency of memory; anxiety to be in company; dreadful nocturnal dreams, when the quantity of liquor through the day has been insufficient; much diminution of appetite, especially an aversion to animal food; violent vomiting in the morning; and excessive perspiration from trivial causes. The above symptoms increase; the pulse becomes small and rapid, the skin hot and dry; but soon a clammy sweat bedews the whole surface of the body; confusion of thought arises to such a height, that objects are seen of the most hideous forms, and in positions that it is physically impossible they can be situated; the patient generally sees flies or other insects, or pieces of money, which he anxiously desires to possess; and often occupies much time and conversations of negotiation, if he be a commercial man. Often, for many days and nights, he will continue without rest, notwithstanding every effort is made on the part of the physician to appease his mind, by variety of conversation, and variety of stimuli. He frequently jumps suddenly out of bed in pursuit of a phantom, and holds the most ineffable contempt for the practitioner, if he do not concur in his proceedings. He commonly retains the most pertinacious opinion that he is not in his own house, and that some of his dearest relations have sustained a serious injury. During the concourse of these symptoms, he often can answer medical questions properly for a short space of time, and then relapse into the raving state.

Today, the criteria for a diagnosis of delirium tremens, published by the American Psychiatric Association in DSM-5, ${ }^{65}$ include delirium (a rapid onset fluctuating disturbance of attention and cognition, sometimes with hallucinations) combined with alcohol withdrawal. ${ }^{66}$

Health professionals now appreciate that alcohol is a depressant of the central nervous system. In the short term, it may produce symptoms of intoxication such as euphoria, exaggerated feelings and loss of self-control: ${ }^{67}$

With repeated exposure, the brain adapts to the effects of alcohol through changes in receptors and other proteins. These adaptions result in decreased effects of the depressant, with the result that higher doses of

[alcohol] ... are required to achieve similar results.

Reductions in blood alcohol levels can lead to alcohol withdrawal symptoms, including insomnia, anxiety and increased pulse rates. Because of the short action of alcohol, withdrawal symptoms usually begin within eight hours after blood alcohol levels decrease. The more serious condition, delirium tremens, usually commences about three days after the appearance of alcohol withdrawal symptoms and lasts two to three days but, in some cases, may be present for eight days or more. ${ }^{68}$

65 American Psychiatric Association Diagnostic and Statistical Manual of Mental Disorders:DSM-5 (5th ed, American Psychiatric Publishing, Arlington (VA), 2013).

66 Marc A Schuckit "Recognition and Management of Withdrawal Delirium (Delirium Tremens)" (2014) 371 N Engl J Med 2109.

67 At 2109.

68 At 2110. 
Delirium tremens may occur in three to five per cent of those who suffer alcohol withdrawal symptoms.

Edwards' medical symptoms, referred to during the course of his trial, did bear a striking resemblance to delirium tremens. He had not consumed, by his standards, a significant quantity of alcohol in the hours preceding the homicide. According to Linehan, Edwards had been served with only one glass of beer about 24 hours before he killed his wife and children. In the hours leading up to the deaths, Edwards appears to have consumed about three glasses of brandy, a quantity that may have caused a level of intoxication but is unlikely to have had much impact on such a profound drinker. If Edwards had drunk in the mid to late afternoon all the brandy in the small flask conveyed to him by his son at about $3.00 \mathrm{pm}$, then he is unlikely to have been intoxicated to any degree at the time of the homicides. The likelihood that Edwards consumed all the brandy in the mid to late afternoon of 10 February is reinforced by Mrs Edwards' comments to William West at about $6.00 \mathrm{pm}$ when she said that her husband had, by that time, suffered "a little attack of some complaint". ${ }^{69}$ This may possibly have been a reference to delirium tremens for which Edwards self-medicated with the brandy.

Of significance was Edwards' own description of the delusions he said he suffered at the time of the homicides and that they occurred after he had suffered several nights with little sleep. Edwards' description of a pack of persons outside his home threatening to burn down his house is a paradigm example of a person suffering from delusions. At the time, Edwards probably did see and hear a crowd of persons outside his house. He also probably believed the crowd intended to burn his home, thereby inflicting a horrific death upon Edwards' wife and children. Edwards' full and frank description to Constable Schulz of the hallucinations he thought he had at the time he killed his wife and children is entirely consistent with the transitory delusions sometimes experienced by those who suffer delirium tremens.

Dr von Mirbach thought that Edwards' description of his delusions to Constable Schulz was consistent with those of a person with delirium tremens. It is also notable that the delusions Edwards reported suffering on the night of 10 February 1884 were generally consistent with the delusional thoughts he had prior to his committal to the Napier Asylum in July and October 1883, and in particular, his belief in October 1883 that a crowd of people were going to shoot him because he had betrayed the secrets of the Freemasons. In both July and October 1883, Edwards' delusions appeared to have been short term, followed by a return to a state of normality. The transitory nature of Edwards' delusions in 1883 are consistent with him having also suffered delirium tremens on those occasions. Some support for this suggestion can be found in Dr Hitchings' evidence, who thought that in July 1883 Edwards showed slight signs of delirium tremens.

69 Gillies J, transcript of evidence, 10 June 1884 at 4. 
The medical evidence presented at Edwards' trial, combined with the evidence that Edwards had consumed little alcohol during the preceding days, his description of having sleepless nights and his explanation of his hallucinations, strongly suggests that at the time he killed his wife and children Edwards was not intoxicated but was suffering from delirium tremens. Compelling support for this conclusion can be found in the letter that Gillies J sent to the Governor with his notes of evidence, in which he said it appeared to him that Edwards killed his wife and family while "under a temporary attack of delirium tremens". ${ }^{70}$

\section{B Homicidal Mania}

Dr Matthews raised the possibility of Edwards having succumbed to homicidal mania, which he associated with delirium tremens. In his evidence, however, Dr von Mirbach said that he had seen a few cases of homicidal mania and that he was confident Edwards did not suffer from that condition.

In 1865, the author of the leading textbook on medical jurisprudence suggested there were three forms of homicidal mania, namely the propensity to kill related to an actual delusion, an absurd motive to kill related to no known motive, or an impulse to kill that was "sudden, instantaneous, unreflective, and uncontrollable". ${ }^{71}$

The meaning that medical professionals assigned to homicidal mania evolved during the second half of the 19th century in response to developing knowledge about forensic psychiatry, and in response to the constraints of the McNaughton Rules. One authority has suggested that homicidal mania gained traction in the late 19th century because it provided an acceptable legal explanation for homicides committed by persons suffering delusions or other recognised medical disorders. ${ }^{72}$

\section{Dr von Mirbach's Opinion}

Dr von Mirbach's rejection of any suggestion that Edwards may have suffered homicidal mania warrants response on three fronts. First, his evidence is difficult to reconcile with the first limb of the definition of homicidal mania in Dr Alfred Taylor's seminal text, namely the propensity to kill related to an actual delusion. As has been previously explained, there was strong evidence that Edwards killed his wife and children because of his delusional belief that a crowd was about to incinerate Edwards and his family and he wished to spare them that form of agonising death. Second, Dr von Mirbach appears not to have drawn the distinction recognised by the common law between intoxication and conditions such as delirium tremens. Instead, Dr von Mirbach appears to have assumed that Edwards killed his wife and children because of the effects of consuming approximately three glasses of

70 Letter from Gillies J to the Attorney-General (13 June 1884) at 1-2.

71 Alfred Swaine Taylor The Principles and Practice of Medical Jurisprudence (J \& A Churchill, London, 1865) at 1106.

72 Joel Peter Eigen "Diagnosis Homicidal Mania: Forensic Psychiatry and the Purposeless Murder" (2010) 54 Med Hist 433. 
brandy, possibly several hours before the homicides occurred. Third, and most strikingly, Dr von Mirbach pronounced that Edwards must have been sane because he felt pain when he attempted to take his own life. There is no reference in any literature or case law to support this proposition. Nor is the basis of this aspect of Dr von Mirbach's evidence immediately obvious. If a person succeeded in killing themselves by cutting their own throat, then their suicide would in all likelihood prevent any meaningful diagnosis of their mental condition. In other words, once dead, it is very difficult to know if the deceased felt pain when cutting their own throat. Dr von Mirbach's evidence on this issue also overlooks the possibility that Edwards may have tried to take his own life after realising he had killed his wife and children when suffering from the "horrors". If so, then Dr von Mirbach appears to have conflated Edwards' state of mind when killing his wife and children and when he attempted to cut his own throat. Given the rapid and transitory nature of delirium tremens, it is quite possible Edwards killed his wife and children when affected by that condition and then subsequently attempted to take his own life in a moment of lucidity.

\section{THE JUDGE'S SUMMING UP}

Care is also required when assessing a trial Judge's summing up to a jury based solely upon newspaper accounts of how the Judge directed the jury. We only have newspaper accounts of Gillies J's summing up as there is no record of his summing up in his bench book, or in his report to the Governor. The newspaper reports of the trial were, however, comprehensive. The report in the Hawke's Bay Herald on 11 June 1884 is very detailed and notes that the Judge's summing up took 25 minutes, during which he impressed: ${ }^{73}$

... upon the jury the nicety and difficulty of determining as to the prisoner's sanity at the time the murder was committed, and [directed] them that only one of two verdicts could be returned. If the jury believed that at the time of the murder the prisoner was absolutely irresponsible for his actions, a verdict of not guilty on account of insanity could be returned. If, on the other hand, they believed [the] prisoner was suffering from partial delusions caused by drink, the law did not allow that to be a palliation of crime, and the verdict must be guilty of wilful murder.

Gillies $\mathrm{J}$ also impressed upon the jury that the onus of proving insanity rested with Edwards and that there was no onus upon the Crown to prove Edwards' sanity. This direction reflected well settled law. The law today continues to presume a defendant sane unless the contrary is proven. ${ }^{74}$ The newspaper reports of the trial did not, however, shed any light on the directions to the jury about the standard of proof that Edwards needed to meet in order to discharge the onus of proving his insanity. Under the McNaughton Rules, Edwards was required to "clearly" prove his insanity. ${ }^{75}$ Today,

73 "Supreme Court - Criminal Sittings", above n 13, at 3.

74 Crimes Act, s 23(1).

75 M'Naghten's Case, above n 49. 
however, a defendant who invokes the defence is required to prove his or her insanity on the balance of probabilities. ${ }^{76}$

\section{A Was Edwards Suffering from a Disease of the Mind?}

A comprehensive summing up to a jury concerning the application of the McNaughton Rules in 1884 would have commenced with a direction that the jury first decide whether or not Edwards was suffering from a disease of the mind when he killed his wife. The only reference to this issue in the newspaper reports of the Judge's summing up is the following opaque direction: ${ }^{77}$

\footnotetext{
Supposing the prisoner to have been suffering from mania at the time the crime was committed, that mania might have been primarily due to indulgence in liquor, or due to brain disease as a secondary result of that indulgence.
}

The approach taken by Gillies $\mathrm{J}$ on this crucial issue was in marked contrast to the directions that Stephen $\mathrm{J}$ gave the jury in $R v$ Davis, in which the jury could have been left in no doubt that if Davis suffered delusions caused by delirium tremens at the time of the attempted murder, then he would have suffered from a disease of the mind that engaged the McNaughton Rules. Instead, Gillies J appears to have invited the jury to consider whether Edwards' delusions were "primarily due to indulgence in liquor" or to "brain disease as a secondary result of that indulgence" ${ }^{78}$ An accurate direction would have drawn a clear distinction between delusions caused by the consumption of alcohol and those that are associated with delirium tremens as a consequence of alcohol withdrawal. If the report of Gillies J's summing up is correct, the jury were not given the benefit of a full and proper direction on whether or not Edwards was actually suffering from a disease of the mind at the time he killed his wife. This is disconcerting because, as emphasised earlier in this article, there was strong evidence to suggest that Edwards was, at the fatal time, suffering delusions triggered by delirium tremens.

The second step in a complete direction on insanity would have required Gillies $\mathrm{J}$ to direct the jury on alternative issues they were required to consider if satisfied Edwards did suffer from a disease of the mind when he killed his wife. Those issues are addressed by asking the following questions:

- $\quad$ Did Edwards understand the nature and quality of the acts he performed when he killed his wife (and children)?

- $\quad$ Did Edwards know his conduct was wrong?

$76 \quad R v$ Cottle [1958] NZLR 999 (CA).

77 "Supreme Court - Criminal Sittings", above n 13, at 3.

78 At 3. 


\section{B Did Edwards Understand the Nature and Quality of the Acts he Performed when he Killed his Wife (and Children)?}

One of the most challenging aspects of applying the McNaughton Rules to Edwards' case was whether he understood the nature and quality of the acts he performed when he killed his wife. This limb of the test of insanity continues to be part of the law of New Zealand. ${ }^{79}$ In the late 1800 s it was thought that this part of the test concerned situations in which the defendant's conduct would not constitute murder if the facts were as he or she believed them to be. For example, where a defendant cuts a person's throat believing they are in fact slicing a loaf of bread, then the McNaughton test would hold that they did not understand the nature and quality of their acts. ${ }^{80}$

Arguably, Edwards' defence counsel was referring to his aspect of the defence of insanity when he impressed upon the jury that: "[t]he delusion that people were about to burn [Edwards] and his family, though unreal, was real to the prisoner, and his crime was the result of that delusion." 81

The reports of Gillies J's summing up contain, however, no reference to this particular limb of the McNaughton Rules.

\section{Did Edwards Know that his Conduct was Wrong?}

If the jury were satisfied Edwards suffered a disease of the mind, but not that he lacked understanding of the nature and quality of the acts that he performed, then the jury would have had to assess whether or not Edwards knew that what he was doing was wrong at the time he killed his wife. This limb of the McNaughton Rules, the Criminal Code Act and the Crimes Act 1908 differed from the current law, which asks if a defendant was "incapable ... of knowing that the act or omission was morally wrong, having regard to the commonly accepted standards of right and wrong". ${ }^{82}$ The reference to "morally" wrong in the current law echoes an aspect of the law of insanity that predated the McNaughton Rules, when juries were asked whether the defendant was "totally incapable of distinguishing between 'good and evil"'. ${ }^{83}$

Properly directed, the jury in Edwards' case would have been asked to consider whether his delusions rendered him incapable of knowing that the act of killing his wife was wrong, or was something he ought not to do. It was on this point that Mr Lee placed much emphasis when he stressed

79 Crimes Act, s 23(2)(a).

$80 R v$ Meade [1909] 1 KB 895 (Crim App); and Director of Public Prosecutions v Beard, above $\mathrm{n}$ 56, at 480.

81 "Supreme Court - Criminal Sittings", above n 13, at 3.

82 Crimes Act, s 23(2).

83 Richard Moran "The Origin of Insanity as a Special Verdict: The Trail for Treason of James Hadfield (1800)" (1985) 19 Law \& Soc'y Rev 487 at 488. See also $R v$ Hadfield (1800) 27 St Tr 1281. 
to the jury that Edwards genuinely believed a crowd was about to inflict horrific deaths upon his wife and children, whom he killed in order to spare them the pain and agony of being burnt to death.

The reports of the Judge's summing up do not refer to Gillies J directing the jury on this specific requirement of this limb of the McNaughton Rules. Instead, if the newspaper reports are accurate, Gillies $\mathrm{J}$ asked the jury to consider whether or not Edwards was "absolutely irresponsible for his actions" and "entirely depriv[ed] ... of the use of his reason". ${ }^{84}$ This aspect of the Judge's directions resonated with the law of Scotland, which, as noted earlier, required a defendant to demonstrate "absolute alienation of reason". ${ }^{85}$ It would be a source of considerable concern if Gillies J did apply the test from Scotland concerning insanity in Edwards' case. The test in Scotland was qualitatively different from the test for insanity in England and New Zealand. In particular, the elements of the McNaughton Rules that a defendant did not know the nature and quality of the act committed, or could not differentiate between right and wrong, were not replicated as discrete elements in the Scots law governing insanity.

The proper approach would have been for Gillies $\mathrm{J}$ to follow the precedent of Stephen $\mathrm{J}$ in $R v$ Davis, in which the jury were specifically asked to consider whether the defendant's delusions rendered him incapable of knowing that his act of attempting to kill the victim was wrong. ${ }^{86}$

\section{Permanent Insanity}

A further troubling aspect of Edwards' trial is the indications the Judge may have laboured under the apprehension that Edwards could not be acquitted on the ground of insanity if his delusions were of a temporary nature. References to this possible line of thinking can be found in the Judge's questioning of Dr von Mirbach, when he asked if the doctor saw signs of "permanent insanity" about Edwards on 11 February 1884; ${ }^{87}$ his references in his note to the Governor that Edwards was under a "temporary" attack of delirium tremens; ${ }^{88}$ and the reported comment in his summing up that if Edwards was suffering "partial delusions" caused by his drinking, then the jury must find Edwards guilty of murder. ${ }^{89}$

84 "Supreme Court - Criminal Sittings", above n 13, at 3.

85 Hume, above n 52.

86 The summing up in $R v$ Davis, above n 58, was reported in Cox's Criminal Cases, copies of which were available in New Zealand in 1884.

87 "Supreme Court - Criminal Sittings", above n 13, at 3.

88 Letter from Gillies J to the Attorney-General (13 June 1884) at 1-2.

89 "Supreme Court - Criminal Sittings", above n 13, at 3. 
If the jury were indeed left with the impression from the Judge's summing up that temporary delusions caused by delirium tremens could not constitute a disease of the mind within the meaning of the McNaughton Rules, then the jury would have been profoundly misdirected.

\section{CONCLUSION}

The accounts of Edwards' trial suggest he was fully resigned to being executed for killing his wife (and children). Edwards told Constable Schulz that he "deserved" to be hung and that, when lucid, he fully appreciated the enormity of his actions. It is possible the swiftness of the jury verdict reflected a phlegmatic desire on its part to put Edwards out of his misery.

Nevertheless, it behoved those responsible for prosecuting Edwards, and the trial Judge, to ensure that his trial conformed in all material respects with the law of New Zealand as at 1884. Serious questions persist as to whether or not the elements of the defence of insanity were accurately explained to the jury. Regrettably, those questions cannot be fully answered in the absence of a complete and accurate record of the Judge's summing up. Suffice to say, the tragedy that beset the Edwards family on 10 February 1884, may have been compounded by the quality of the trial that resulted in Edwards' execution in circumstances where a verdict of not guilty by reason of insanity was reasonably available. 
